\title{
Tracing the Canary islands hotspot back to the Mesozoic: isotopic evidence from the Central High Atlas basalts, Morocco
}

\author{
S. TOMMASINI ${ }^{1}$, A.P. SANTO $^{1,2}$, M. CASALINI ${ }^{1}$, L. \\ VALERIANI $^{1}$, E. BRASCHI ${ }^{2}$, M. BENVENUTI ${ }^{1,2}$, L. \\ FRANCALANCI ${ }^{1,2}$ \\ ${ }^{1}$ Dipartimento di Scienze della Terra, Università di Firenze, \\ Italy (*correspondence: simone.tommasini@unifi.it) \\ ${ }^{2} \mathrm{CNR}$, Istituto di Geoscienze e Georisorse, Firenze, Italy
}

The Atlas domains were affected by three magmatic events during the Early Jurassic, the Middle-Late Jurassic to Early Cretaceous, and the Cenozoic. The first event is related to Pangea breakup and emplacement of the Central Atlantic Magmatic Province (CAMP) basalts. The second event consists of basaltic lava flows and subvolcanic intrusive complexes outcropping in the Central High Atlas (CHA). The last event consists of alkaline basalts outcropping in the Middle and Anti Atlas domains.

The studied CHA basalts have a restricted compositional range and are transitional between alkaline and subalkaline magmas. The geochemical and radiogenic isotope signature of the CHA basalts can help to bridge the temporal and mantle source gap from the CAMP to the Cenozoic magmatism occurring in the Atlas domains and culminating in the present-day plume activity of the Canary Islands.

We propose that, after the CAMP magmatic event, the present-day Canary Islands mantle plume impinged at the base of the lithosphere underneath the Atlas domains, producing the CHA basalts along with lithosphere delamination. The African plate movement towards NE, in response to the Central Atlantic sea floor spreading, determined dragging of the plume head and lithosphere delamination, and formed an asymmetric flattened plume head. During lithosphere movement, the plume progressively created direct routes to the surface without interacting with the lithospheric mantle and generated the Cenozoic basalts occurring in the Anti Atlas and Middle Atlas domains up to the present-day Canary Islands magmatism. The arrival of the plume explains the occurrence of the anomalously thinned lithosphere beneath the Atlas domains $(60-80 \mathrm{~km})$ in comparison with typical NW African lithosphere (130-160 $\mathrm{km})$. This thinned delaminated subcontinental lithosphere forms a narrow ENE-WSW corridor overlain by the CHA and Cenozoic magmas, and can represent the trail of the dragged plume head. 